ISSN: 2536-5339

\title{
Elit Türk Sporcularında Anjiotensin Dönüştürücü Enzim (I / D) Polimorfizmi ile Sportif Performans Arasındaki İlişkinin İncelenmesi ${ }^{1}$
}

\author{
Melahat KURTULUŞ ${ }^{1} \quad$ Mehmet GÜNAY $^{2}$ Ebru ÇETIN ${ }^{2}$ Çağrı ÇELENK ${ }^{3}$ \\ İbrahim CicioĞLU ${ }^{2}$ Ebru ALP ${ }^{4}$ Meral YIRMIBEŞ KARAOĞUZ $^{5}$ \\ Tahsin KESiCi ${ }^{6}$
}

${ }^{1}$ Gazi Üniversitesi Eczacılık Fakültesi, ANKARA

${ }^{2}$ Gazi Üniversitesi Spor Bilimleri Fakültesi, ANKARA

${ }^{3}$ Erciyes Üniversitesi Spor Bilimleri Fakültesi, KAYSERI

${ }^{4}$ Giresun Üniversitesi Tıp Fakültesi, GIRESUN

${ }^{5}$ Gazi Üniversitesi Tıp Fakültesi, ANKARA

${ }^{6}$ TOBB Ekonomi ve Teknoloji Üniversitesi, ANKARA

Künye: : Kurtuluş, M., Günay, M., Cicioğlu, İ., Çetin, E., Çelenk, Ç., Alp, E., Yirmibeş Karaoğuz, M. ve Kesici, T. (2018). Elit Türk Sporcularında Anjiotensin Dönüştürücü Enzim (I / D) Polimorfizmi ile Sportif Performans arasındaki İlişkinin İncelenmesi. Gaziantep Üniversitesi Spor Bilimleri Dergisi, 3(4): 122-137.

\section{Öz}

ACE geni plazma ve dokularda ACE düzeylerini belirler. Anjiotensin dönüştürücü enzim geni fiziksel aktivite ile ilişkili önemli bir gendir. Bu çalışmanın amacı elit Türk sporcularından (dayanıklılık ve kuvvet sporcusu) oluşan bir populasyonda (kayak, hentbol, voleybol, güreş) ACE geni I/D polimorfizmi ile spor performansı arasında bir ilişki olup olmadığını belirlemektir. Her bir bireyin ACE geni I/D polimorfizmi genotip dağılımı polimeraz zincir reaksiyonu yöntemiyle belirlendi. 114 elit Türk sporcusu dayanıklılık (18) ve kuvvet (96) sporcuları olmak üzere iki gruba ayrıldı. Sporcuların ACE geni I/D polimorfizmi genotip ve alel frekansları; 114 elit sporcu, her bir sporcu grubu, dayanıklılık sporcuları ve kuvvet sporcuları olmak üzere dört ayrı katagoride kontrol grubu (95) ile karşılaştırıldı. Ayrıca her bir spor grubundaki sporcular ile dayanıklılık ve kuvvet sporcuları birbirleriyle Ki-kare and Fisher exact testi ile karşılaştırıldı. Elit Türk sporcu ile kontrol grubu ve diğer kategoriler arasında yapılan karşılaştırmalarda ACE geni I/D polimorfizmi genotip dağılımı ve alel frekanslarında istatistiksel olarak anlamlı bir fark tespit edilmedi $(p>0.05)$

Anahtar Kelimeler: Anjiotensin Konverting Enzim, Polimorfizm, Atletik Performans

\section{Orijinal Makale}

\section{Yayın Bilgileri}

Gönderi Tarihi: 31.10.2018

Kabul Tarihi: 29.11.2018

Yayın Tarihi: 28.12.2018

\section{Sorumlu Yazar}

e-mail: melahatkurtulus@hotmail.com

DOI: $10.31680 /$ gaunjss.476196

\footnotetext{
${ }^{1}$ Gazi Üniversitesi BAP projesi kapsamında (14/2004-03) desteklenmiştir.
} 


\section{Investigation of the Relationship Between Angiotensin Converting Enzyme (I / D) Polymorphism and Sportive Performance in Elite Turkish Athletes}

\begin{abstract}
The ACE gene determines ACE levels in plasma and tissues. Angiotensin converting enzyme gene is an important gene, which is associated with the physical activity. The aim of this study is to determine whether there is a relationship between ACE gene I/D polymorphism and sports performance in population (cross-country skiing, handball, volleyball, wrestling) including elit Turkish athletes (endurance and strength athletes). Genotype distribution of the ACE gene I/D polymorphism for each subject was determined by polymerase chain reaction method. 114 elite Turkish athletes were divided into two groups as endurance (18) and strength athletes (96). ACE gene genotype and allele frequencies of athletes; 114 elite athletes, each group of athletes, endurance athletes and strength athletes were compared with the control group (95) in four different categories. In addition, athletes in each sport group and the endurance and strength athletes were compared with each other by Chi-square and Fisher exact test. There was no statistically significant difference in allele frequencies and genotype distribution of the ACE gene I/D polymorphism in the comparison of elite Turkish athletes with control group and other categories $(p>0.05)$.
\end{abstract}

Key Words: Angiotensin Converting Enzyme, Polymorphism, Athletic Performance

\section{Original Article}

\section{Article Info}

Received: 31.10.2018

Accepted: 29.11 .2018

Published: 28.12.2018

Corresponding Author

e-mail:

melahatkurtulus@hotmail.com

\section{Giriş}

Spor performansı eğitim, diyet, çevre, genetik ve diğer birçok faktörden etkilenebilen bir özelliktir. Genetik bilgi vücut şeklinin belirlenmesinde rol oynar. Ayrıca kuvvet, akciğer kapasitesi, esneklik, dayanıklılık, boyut ve kasların lif kompozisyonu, anaerobik eşik ve egzersiz sırasında vücuda oksijen alınımı ve dağılımında kardiyo-solunum sistemi kapasitesiyle bağlantılı maksimum oksijen alımında $\left(\mathrm{VO}_{2 \max }\right)$ etkilidir (Macarthur ve ark., 2005; Ostrander ve ark., 2009).

Spor disiplinine bağlı olarak sporcu başarısında genetik faktörlerin \% 66 oranında katkı sağladığı ikizlerle yapılan bir çalışmada gösterilmiştir (De Moor ve ark., 2007). Fiziksel performansla ilişkili 200 genetik varyasyon tanımlanmış ve bunlardan bir kaçının atletik performanstaki önemi vurgulanmıştır (Bray ve ark., 2009). Otozomal gen, mitokondriyel DNA ve Y-kromozomunda bulunan ve kişiler arası genetik farklılıklara neden olan DNA polimorfizmlerinin elit sporcu olma ve bireyin egzersize verdiği cevaplarla bağlantıları gösterilmiştir (Ahmetov ve Rogozkin, 2009). İnsan fiziksel performansında etkili ilk genetik polimorfizmin anjiotensin I-dönüştürücü enzim geninde (ACE) olduğu bildirilmiştir (Montgomery ve ark., 1998).

ACE geni 17. kromozomda (17q23.3) bulunur ve 21 kb uzunluğundadır (Mattei ve ark.,1989). Bu genin ürünü, inaktif anjiyotensin l'in renin-anjiyotensin sisteminin (RAS) ana ürünü olan anjiyotensin II'ye (aktif form) dönüşümünü katalize eder (Oktem ve ark., 2004) ve bir büyüme inhibitörü olan bradikinin degradasyonunu 
artırarak arteriyel kan basıncının düzenlenmesini sağlar (Murphey ve ark., 2000). Anjiyotensin II aldosteronun uyarılmasında önemli bir role sahiptir ve böbreklerde daha fazla sodyum ve suyun geri emilimine neden olur ve hem kandaki hem de kan basıncındaki sıvı miktarını arttırır (Brewster ve Perazella, 2004). ACE enziminin miktarındaki artış anjiotensin II hormonunun artışına neden olur.

Rigat ve arkadaşları ACE geni intron 16 polimorfizminin, ACE enzimi plazma seviyelerini genetik olarak kontrol edebildiğini göstermiştir (Rigat ve ark., 1990). ACE insersiyon/delesyon polimorfizmi (ACE I/D) intron 16'da 287 baz çifti (bç) uzunluğundaki Alu tekrar dizisinin eklenmesiyle (insersiyon: I aleli) veya yokluğuyla (delesyon : D aleli) tanımlanır (Williams ve ark., 2000). ACE geni üç farklı genotip (II, ID ve DD) ile ifade edilir. ACE polimorfizmi kodominanttır ve heterozigot durumda her iki alel etkisini gösterir.

ACE genotipinin elit sporcuların kas gücünde (Cieszczyk ve ark., 2009; Costa ve ark., 2009), uzun mesafe koşucularında kardiyovasküler sistem morfolojisinde ve sol ventrikül hipertrofisinde önemli bir role sahip olduğu bilinmektedir (Nagashima ve ark., 2000).

Zhang ve arkadaşları ACE geni I alelinin tip I kas lif büyüklüğünün (yavaş kasılan kas fibril) artışıyla bağlantıı olabileceğini ifade etmişlerdir. Bu bağlantı iyi bir fiziksel fitnes ve ACE geni I aleli arasında mekanik bir ilişki olduğunu vurgulamaktadır (Zhang ve ark., 2003). 11-haftalık egzersiz sonrası İngiliz askerlerinde yapılan bir araştırma ACE I alel varlığının iskelet kasının mekanik etkinliğini artırdığını (kas lifleri) göstermiş̧ir (Williams ve ark., 2000). Diğer çalışmalar ACE I/D polimorfizminin oksijen alım düzeyini etkilemediğini ancak fiziksel fitnes'ı arttıran bir faktör olabileceğini belirtmişlerdir (Woods ve ark., 2002).

ACE D aleli ile hızı kasılan tip II kas lifleri arasında da bir ilişki saptanmışıı (Folland ve ark., 2000). İskelet kasındaki ACE gen polimorfizminin atletik performansa katkısını belirlemek amacıyla çeşitli çalışmalar yapıımıştır. Bu analizıer belirli bir polimorfizmin veya alelin bir kontrol grubuyla karşılaştırılarak sporculardaki sıkığını belirlemeye yöneliktir. 1996 yılında, Avustralya ulusal kürek ekibindeki sporcularda sıklıkla II ve ID genotipleri tespit edilmiştir (Gayagay ve ark., 1998). ACE geni I/D polimorfizminin aerobik dayanıklılık üzerine etkisi 25 elit İngiliz dağcısında $(7,000 \mathrm{~m})$ araştırılmış ve yüksek oranda II genotipi tespit edilmiştir (Montgomery ve ark., 1998). 
İnsersiyon genotipi (II) yoğun ve uzun süreli fiziksel egzersiz sırasında enerji dengesinin korunmasını sağlayan dokulardaki düşük aktiviteli enzimi tanımlar. Dağcllık, uzun mesafe yüzme ve uzun mesafe koşusu gibi aerobik enerji gerektiren spor dallarında ACE II genotipinin yaygın olduğu görülmüştür (Jones ve ark., 2002; Myerson ve ark., 1999; Tsianos ve ark., 2004). DD genotipi ve yüksek düzeyde ACE aktivitesi kısa mesafe yüzme, kısa mesafe koşusu ve bisiklet yarışı gibi anaerobik metabolizma özelliğine sahip spor dallarındaki sporcularda yaygındır (Ahmetov ve Fedotovskaya, 2015; Eider ve ark., 2013; Lucia ve ark., 2005).

Elit sporcu durumu ve ACE I/D polimorfizmi arasında ilişki saptanmamış birçok çalışma bulunmaktadır (Taylor ve ark., 1999). Bir grup araştırıcı uzun ve orta mesafe koşusu, yol bisikleti, kayaklı koşu ve atıcılık gibi dayanıklılık disiplinlerinde I alel sıklığının beklendiği kadar yüksek olmadığını ve ACE gen polimorfizminin kardiyorespiratuvar etkinlikte rol oynamadığını göstermiştir (Rankinen ve ark., 2000). Etnik ve coğrafik farklılıklar gösteren Amerikan askerlerine (kadın ve erkek) genel fiziksel egzersiz uygulanmış ve ACE genotipi ile aerobik kapasite arasında güçlü bir etki olmadığı saptanmıştır (Sonna ve ark., 2001). Kuvvet egzersizi uygulanan D aleli taşıyan ikizler ile kas gücü arasında bir bağlantı belirlenmemiştir (Thomis ve ark., 2004). Dünya standartlarında 230 Kenyalı kısa mesafe koşucusunda D aleli taşıyanların sayısının az olması ACE geni ile koşucu arasında bir ilişki olmadığını göstermiştir (Scott ve ark., 2005).

ACE I/D polimorfizmi ve elit sporcu durumuyla ilgili bu farklılıklar ACE I ve D değişkenlerinin gerçekten fiziksel performansı etkileyebilecek genetik faktör olup olmadığına karar verilmesini zorlaştırmaktadır.

$\mathrm{Bu}$ araştırma, ACE geni (I/D) polimorfizmi genotip dağııımı ve alel frekanslarının elit Türk sporcularının başarısına katkıda bulunabilecek genetik bir unsur olup olmadığını araştırmak için yapıldı. Elit Türk sporcuların genotip ve alel frekansları sedanter bireylerin frekanslarıla, her bir sporcu grubu birbirleriyle ve dayanıklıık / kuvvet sporcuları kendi aralarında ve sedanter bireylerle karşılaştııılı.

\section{Yöntem}

\section{Araştırma Grubu}

114 Türk elit sporcudan; kayak $(n=18)$, hentbol $(n=15)$, voleybol $(n=12)$ ve güreş $(n=69)$ ve akraba ilişkisi olmayan 95 sedanter bireyden (kontrol grubu) kan örnekleri alındı. 


\section{ACE (I/D) Polimorfizminin Belirlenmesi}

Genomik DNA kan örneklerinden standard protokol kullanılarak elde edildi (Sambrook ve ark., 1989). Her bir bireyin ACE geni genotip dağılımı ve alelleri ACE ve I (insertion)-spesifik primerler kullanılarak PZR yöntemiyle belirlendi (Rigat ve ark., 1992).

PZR reaksiyonu ACE primerleri; 5'-CTGGAGACCACTCCCATCCTTTCT-3' ve 5'-GATGTGGCCATCACATTCGTCAGAT-3' kullanılarak yapıldı. ACE PZR şartları: başlangıç denaturasyon $95^{\circ} \mathrm{C} 5 \mathrm{dk} ; 30 \mathrm{kez} 95^{\circ} \mathrm{C} 30 \mathrm{~s}, 58^{\circ} \mathrm{C} 30 \mathrm{~s}, 72^{\circ} \mathrm{C} 1 \mathrm{dk}$ ve son uzama $72^{\circ} \mathrm{C} 5 \mathrm{dk}$ 'dır. PZR ürünleri \% 1,5 agaroz jel elektroforezine yüklendi. PZR ürünlerinin büyüklüğüne göre her bir örneğin $A C E$ geni alelleri (I/D) ve genotip dağılımı belirlendi. 190 bç uzunluğundaki amplifiye ürün $D$ aleli ve 490 bç uzunluğunda olan ise I aleli olarak değerlendirildi.

Bazı yorumlara göre; PZR tepkimesi sırasında heterozigot bireylerde I aleli baskılanmış olabileceğinden işlem sırasında kısa D alelinin tercih edileceği olası görülmektedir. ID heterozigot genotipinin DD genotipi şeklinde yanlış sınıflandırılmasını önlemek için, başlangıçta DD genotipi olarak belirlenen tüm örneklerde hace5a, 5'-TGGGACCACAGCGCCCGCCACTAC-3' ve hace5c, 5'TCGCCAGCCCTCCCATGCCCATAA-3' şeklindeki I (insertion)-spesifik primer çiftleri (HACE) kullanılarak ikinci bir PZR yapıldı.

İkinci PZR şartları, sadece anneling derecesi $\left(64^{\circ} \mathrm{C}\right)$ hariç ACE'nin çoğaltılmasındaki PZR şartlarına benzerdir. Amplifiye ürünlerde 335 bç uzunluğunda bir fragmentin gözlenmesi I aleli varlığını gösterdi. D aleli homozigot ise herhangi bir fragment oluşmadı (Lindpaintner ve ark., 1995).

\section{İstatistiksel Analiz}

Alel frekansları gen-sayma metoduyla hesaplandı. ACE geni I/D polimorfizmi alel ve genotip frekansları toplam elit sporcu, her bir sporcu grubu birbirleriyle ve dayanıklılık ve kuvvet sporcuları kendi aralarında ve kontrol grubu ile Ki-kare veya Fisher exact testi $(\mathrm{N}<5)$ kullanılarak karşılaştırıldı. $\mathrm{P}<0.05$ değeri istatistiksel olarak önemli kabul edildi. Elit sporcu ve kontrol grubu genotip frekanslarının HardyWeinberg dengesinde olduğu tespit edildi. 


\section{Bulgular}

ACE geni I/D polimorfizminin elit Türk sporcularının başarısında etkisinin olup olmadığını belirlemek amacıyla 114 elit Türk sporcu ve 95 sağlıklı sedanter bireyin ACE geni I/D polimorfizmi genotip dağılımı ve alel frekansları araştırıldı.

Elit Türk sporcu ve kontrol grubu bireylerinden alınan kan örneklerinden standart protokol kullanılarak DNA elde edildi. 114 elit Türk sporcu ve 95 sağlıklı sedanter bireyin DNA'ları ACE primerleri kullanılarak PZR yöntemiyle çoğaltıldı. I (insertion)-spesifik primerlerle ikinci bir PZR işlemi genotipi DD olarak belirlenen örneklere uygulandı. Sporcu ve sedanter bireylerin ACE geni I/D polimorfizmi alel ve genotipleri belirlendi.

Elit Türk sporcuları dayanıklılık sporcuları (18) ve kuvvet sporcuları (96) olarak iki grupta incelendi. Dayanıklılık sporcu grubunu kayaklı koşucu $(n=18)$ ve kuvvet sporcu grubunu ise hentbolcu $(n=15)$, voleybolcu $(n=12)$, güreşci $(n=69)$ gibi sporcular oluşturdu.

Dayanıklılık ve kuvvet sporcularında ACE geni I/D polimorfizmi alel ve genotip frekansları hesaplandı. Dayanıklılık ve kuvvet sporcuları frekansları birbiriyle ve kontrol grubu ile karşılaştırıldı ve gruplar arasında bir fark görülmedi (Tablo 1).

Tablo 1.

Dayanıklılık ve Kuvvet Sporcularında ACE I/D Genotip Dağılımı ve Alel Frekansları

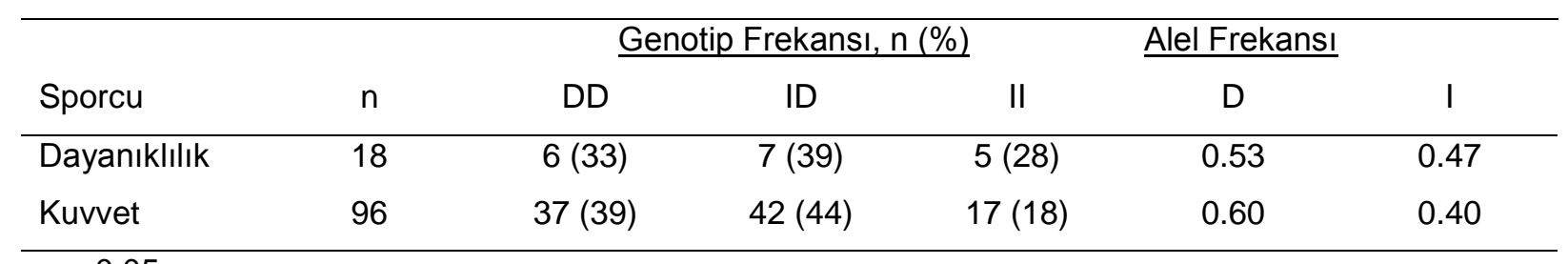

$\mathrm{p}>0.05$

ACE geni II genotipinin kuvvet sporcularından çok dayanıklılık sporcularında (kayaklı koşucu) yaygın olduğu gözlendi. Dayanıklılık ile kuvvet sporcuları karşılaştırıldığında ACE geni DD genotipinin dayanıklılık sporcularında daha fazla olduğu tespit edildi (Tablo 1).

Ayrıca her bir sporcu grubunun (kayaklı koşu, hentbol, voleybol ve güreş) ACE geni I/D polimorfizmi genotip ve alel frekansları birbirleriyle ve kontrol grubu frekanslarıyla karşılaştırıldı (Tablo 2). Her bir gruptaki sporcuların ACE geni I/D polimorfizmi genotip dağılımı ve alel frekansları ile kontrol grubu frekansları arasında bir fark tespit edilmedi $(p>0.05)$. 


\section{Tablo 2.}

Elit Türk Sporcuları ve Kontrol Grubundaki ACE I/D Genotip Dağılımı ve Alel Frekansları

\begin{tabular}{|c|c|c|c|c|c|c|}
\hline \multirow[b]{2}{*}{ Sporcu } & \multirow[b]{2}{*}{$\mathrm{n}$} & \multicolumn{2}{|c|}{ Genotip Frekansı, n (\%) } & \multicolumn{2}{|c|}{ Alel Frekansı } & \multirow[b]{2}{*}{ I } \\
\hline & & DD & ID & II & D & \\
\hline Kayak & 18 & $6(33)$ & $7(39)$ & $5(28)$ & 0.53 & 0.47 \\
\hline Hentbol & 15 & $3(20)$ & $9(60)$ & $3(20)$ & 0.50 & 0.50 \\
\hline Voleybol & 12 & $4(33)$ & $5(42)$ & $3(25)$ & 0.54 & 0.46 \\
\hline Güreş & 69 & $30(43)$ & $28(41)$ & $11(16)$ & 0.64 & 0.36 \\
\hline Toplam & 114 & 44 (39) & $48(42)$ & 22 (19) & 0.60 & 0.40 \\
\hline Kontrol & 95 & $36(38)$ & $45(47)$ & $14(15)$ & 0.61 & 0.39 \\
\hline
\end{tabular}

$p>0.05$

114 elit Türk sporcu ve kontrol grubunda (95) sıklıkla D aleli taşıyan bireylerin (DD+ID) I aleli taşıyanlardan fazla olduğu belirlendi (Tablo 2). Elit sporcu ve kontrol grubu ACE genotip frekanslarının Hardy-Weinberg dengesinde olduğu tespit edildi.

\section{Tartışma ve Sonuç}

İnsan özelliklerinin anlaşılmasında genetik alt yapı, genler arasındaki etkileşim ve epigenetik değişimlerin bilinmesi önemlidir. Moleküler genetikçiler karmaşık düzenleyici sistemlerde bazı alellerin etkilerini araştırmışlardır (Phillips, 2008). DNA polimorfizmi gibi moleküler belirteçlerin belirli spor dallarında başarıya katkı sağladığı bildirilmiştir (Ahmetov ve Fedotovskaya, 2015). Bir gen lokusunda iki ya da daha fazla alel bulunması durumu polimorfizmdir. Genetik polimorfizmler bazı insan özelliklerinde farklılıklara neden olur. Alellerin farklılığına göre, iki ya da daha fazla farklı özelliklerde fenotip görülür (Puthucheary ve ark., 2011). Spor biliminde şimdiye kadar en çok çalışılan polimorfizm ACE geni I/D polimorfizmidir (Montgomery ve ark., 1998).

ACE geni I/D polimorfizm alellerinin atletik yetenek üzerinde farklı etkileri olduğu tespit edilmiştir; I alelinin dayanıklılık performansıyla (Collins ve ark., 2004; Ma ve ark., 2013; Myerson ve ark., 1999), D alelinin ise kuvvet ve güç sporlarıyla ilişkisi gösterilmiştir (Woods ve ark., 2001). ACE gen ürünü RAS sisteminin önemli bileşenlerindendir (Jones ve ark., 2002). ACE geninin hem kardiyak hem de vasküler sistemlerdeki düzenleyici etkisi bu genin atletik performansla ilişkili bir aday gen olabileceğini göstermektedir (Gayagar ve ark., 1998).

Bu çalışmada elit Türk sporcular spor disiplinine göre iki grupta sınıflandırıldı (dayanıklılık ve kuvvet sporcuları) ve ACE geni I/D polimorfizminin Türk sporcularının başarısında etkisi olup olmadığı araştırıldı. Dört farklı spor dalındaki (kayaklı koşu, hentbol, voleybol, güreş) dayanıklılık ve kuvvet sporcuları ACE geni I/D polimorfizm dağılımı sedanter bireylerle karşılaştırılarak analiz edildi. Sporcular ile sedanter 
bireyler arasında ACE geni I/D polimorfizminin genotip dağılımı ve alel sıklığında anlamlı bir fark bulunamadı ( $p$ 0.05). Dört spor dalındaki elit sporcu frekansları birbirleriyle, dayanıklılık ve kuvvet sporcuları kendi aralarında ve sedanter bireylerle karşılaştııılı̆̆ında bir farklılık tespit edilmedi ( $p>0.05)$.

Yüksek aerobik fitnes gerektiren birçok spor dalındaki Avustralyalı milli sporcularda ACE genotip ve alel frekanslarında bir fark saptanmamıştır (Taylor ve ark., 1999). Rankinen ve arkadaşları bu yaklaşımın, çalışma tasarımı, populasyon örnek büyüklüğü ve fenotip ölçümü gibi faktörlerden kaynaklanabileceğini bildirmişlerdir (Rankinen ve ark., 2000).

Farklı spor disiplinleri ile ACE geni I/D polimorfizmi arasındaki ilişki çok ilgi çekicidir fakat aralarında bağlantı kurmak zordur. Bazı heterojen yapılı çalışmalarda (Irk, cinsiyet ve karma spor disiplinleri) atletik performans ve ACE polimorfizmi arasında bir ilişki tespit edilmemiştir (Drozdovska ve ark., 2013; Orysiak ve ark., 2013). Etnik grup ve karma spor disiplinlerinde ACE genotip dağılımının değerlendirildiği diğer çalışmada ACE II genotipinin fiziksel performans artışıla ilişkisi saptanmıştır (Ma ve ark., 2013). ACE geni ve performans arasında cinsiyete göre değişen önemli bağlantılar olduğu çeşitli araştırmalarda gösterilmiştir (Costa ve ark., 2009; Min ve ark., 2009; Moran ve ark., 2006).

Bu çalışmada dayanıkııık ve kuvvet sporcuları karşılaştıııdı ve dayanıkııık sporcularında (kayaklı koşucu) ACE geni II genotipinin kuvvet sporcularına göre daha yaygın olduğu gözlendi. Kuvvet sporcularında ACE geni DD genotipinde fazlalık tespit edildi (Tablo 1). ACE geni $D$ alelinin elit kuvvet sporcusunu olumlu yönde etkilediğini gösteren birçok çalışma vardır (Günel ve ark., 2014). Bu alelin fazlalığı kısa mesafe koşucuları ve yüzücülerinde gözlenmiştir (Nazarov ve ark., 2001; Tsianos ve ark., 2004; Woods ve ark. 2001). Papadimitriou ve ark.'nın yaptığı bir çalışmada, elit Yunan atletizm sporcularında ACE DD genotipinin kuvvet performansı üzerinde zayıf bir etkisi olduğu bildirilmiştir (Papadimitriou ve ark., 2009).

Bu araştırmada 114 elit Türk sporcu ve kontrol grubunda (95) sıklıkla D aleli taşıyan bireylerin (DD+ID) I aleli taşıyanlardan fazla olduğu tespit edildi. Japon erkek koşucu ile yarış mesafesi (kısa, orta ve uzun mesafe) arasındaki ACE I/D polimorfizm dağılımı ve bu polimorfizmin cinsiyet üzerindeki etkisini araştıran bir çalışma, multinomial lojistik regresyon analiziyle kısa-mesafe ve uzun-mesafe koşucularında yüksek oranda ACE geni ID genotipi tespit etmişlerdir. Kısa ve uzun mesafe koşucuları ve tekvandocularda sıklıkla ID genotipinin görülmesi heterozigot ID 
genotipinin baskın bir fenotip oluşturamaması nedeniyle gerçekleştiği düşünülmektedir (Günay ve ark., 2010; Min ve ark., 2009).

Bu çalışmada elit Türk güreşcilerin ACE geni genotip dağılımı ile kontrol grubu arasında bir farklılık bulunamadı. Elit Türk güreşcilerde ACE geni DD genotip frekansının kontrol grubundan fazla olduğu tespit edildi. Polonyalı ulusal kuvvet sporcu grubunda genotip dağıımı kontrol grubundan önemli ölçüde farklı bulunmuş ve D alelinde önemli bir artış görülmüştür (Eider ve ark., 2013). ACE ve aktin-3 gen polimorfizmleri kombinasyonunun Japon elit güreşcilerinde atletik performansla ilişkisi gösterilmiştir (Kıkuchi ve ark., 2012). Birçok çalışma ACE geni D alelinin sporcu başarısında rol oynadığını göstermektedir. Aksine uluslararası (yüksek performans) ve ulusal (orta düzeyde performans) düzeyde yarışan kuvvet sporcularını karşılaştıran bir çalışmada performans seviyesinin artmasıyla DD genotip frekansında kademeli bir azalma olduğu görülmüştür (Kim ve ark., 2010). Scott ve arkadaşları Jamaika ve Amerikalı sporcularda ACE DD genotipinin kuvvet performansında anahtar bir rol oynamadığını göstermişlerdir (Scott ve ark., 2010).

Çalışmada elit Türk voleybolcu, kayaklı koşucu, ve hentbolcu grupları birbirleriyle ve tüm sporcular kontrol grubuyla karşılaştırıldığında ACE geni I/D polimorfizminin alel/genotip dağılımında bir fark tespit edilmedi. Ülkemizde basketbol ve voleybolcularla ilgili yapılan benzer bir çalışmada sporcular ve kontrol bireyler arasında farklılık gözlenmemiştir (Süel ve Pehlivan, 2015). 80 Türk dayanıklılık ve kuvvet sporcularını kapsayan bir çalışma (orta mesafe koşma, basketbol, hentbol ve futbol) ACE I/D polimorfizminin Türk sporcularının fiziksel performansını etkileyen bir genetik faktör olduğunu göstermiştir (Turgut ve ark., 2004).

Koreli erkek elit basketbol, judo, futbol, jimnastik, uzun mesafe koşucusu, buz hokeyi oyuncusu ve voleybolculardaki ACE I/D polimorfizm dağılımı ile kontrol grubundaki dağıım arasında fark olmadığı tespit edilmiştir (Oh, 2007). Üç farklı spor disiplinini kapsayan bir çalışmada voleybol ve hentbol oyuncularında ACE geni alel/genotip frekanslarında istatistiksel bir fark olmadığı bildirilmiştir (Durmic ve ark., 2017). Alvarez ve arkadaşları İspanyol elit sporcularda (15 hentbolcu, 20 uzunmesafe koşucusu ve 25 bisikletçi) ACE I alelinin önemli ölçüde yüksek frekansa sahip olduğunu belirlemişlerdir (Alvarez ve ark., 2000).

Kayaklı koşucu ve ACE polimorfizmi arasında bir ilişki olmadığını gösteren çeşitli çalışmalar bildirilmiştir (Rankinen ve ark., 2000; Taylor ve ark., 1999). İtalya'da aerobik ve anaerobik disiplinleri kapsayan kayaklı koşucuların bulunduğu karma 
çalışmada sporcuların tümünde ACE I/D polimorfizmi genotip frekans dağııımı ile sağlıkı İtalyan bireyleri arasında bir fark tespit edilmemiştir. Aynı araştırmada iki farklı spor disiplinindeki (aerobik ve anaerobik) sporcu grubları kendi aralarında karşıllaşıırıldığında sporcu genotiplerinde önemli bir fark saptanmış $(P=0.03)$, ancak allelerinde farklılık tespit edilmemiştir (Scanivini ve ark., 2002).

Elit sporcular arasında ACE I alelinin frekansında görülen artış ACE I/D polimorfizminin fiziksel performansı etkileyen bir genetik faktör olabileceğini öngörmektedir (Alvarez ve ark., 2000). Atletik performans ve ACE I/D polimorfizmiyle ilişkili bazı çelişkili kanıtlar vardır. Etiyopyalı dayanıkııık sporcularındaki ACE I/D polimorfizm genotip frekanslarının kontrol grubu frekanslarından farklı olmadığı bildirilmiştir (Ash ve ark., 2011). Yüksek aerobik fitnes gerektiren birçok spor dalındaki Avustralyalı milli sporcularda ACE genotip ve alel frekanslarında da bir fark saptanmamışıtı (Taylor ve ark., 1999). Rankinen ve arkadaşları bu yaklaşımın, çalışma tasarımı, populasyon örnek büyüklüğü ve fenotip ölçümü gibi faktörlerden kaynaklanabileceğini bildirmişlerdir (Rankinen ve ark., 2000).

Bazı araşıımalarda sporcu olmayan yetişkinlerde $D$ aleli ve patlayıcı kas gücü arasında çok zayıf bir ilişki, bu alelin kuvvet/güç performansı ile ilişkisinin olmaması, kuvvet sporcularında $D$ alelinin yetersiz temsil edilmesi ve $D$ alelinin bazı etnik gruplarda kuvvet/güç aktivitesi yerine dayanıkılık performansını artırdığı bulgusu gibi oldukça zıt sonuçlar elde edilmiştir (Kim ve ark.,2010; Moran ve ark., 2006; Scott ve ark., 2010; Shahmoradi ve ark., 2014).

Çalışmaların anaerobik ve aerobik enerji üretimi gerektiren karma spor disiplinleri yerine daha çok homojen spor disiplinlerinde yapılmasının faydalı olacağı bildirilmiştir (Oh, 2007). Dayanıklılık performansı ile ACE genotipinin uzun süreli egzersiz yapan sporcularla ilişkilendirilmesi elit sporcu yeteneğinde genetik özelliğin yanısıra egzersiz gibi çevresel faktörlerinde etkili olduğunu göstermiştir (Bayraktar ve Kurtoğlu, 2009; Sercan ve ark., 2016, Spriet, 2018).

Bazı araştırmalarda ACE genotipi ve elit sporcu yeteneği arasında bir ilişki gösterilememesi ACE I/D polimorfizminin elit sporcu olma durumu ile ilgisinin olmadığını göstermez. Küçük örnek büyüklüğü ile yapılan araştırmalar sadece araştırmanın istatistiksel gücünü azaltmakla birlikte aynı zamanda spor bilimine verdiği katkı nedeniyle sahte pozitif bulgular elde edilmesine yol açabilmektedir. Bu nedenle küçük grublarla yapılan çalışmaların benzerinin örnek sayısı fazla olan gruplarda tekrarlanması önemlidir. 
Bu çalışmada elit Türk sporcuları ile ACE I/D polimorfizmi arasında bir ilişki tespit edilmedi. Heterojen gruplarda sporcu-gen arasında bir ilişki tespit edilmesinin zor olduğu bilinmektedir. Gelecekte insan performansında ACE I/D polimorfizminin rolünü açıklayacak çalışmaların homojen sporcu grubunda yapılmasının muhtemelen daha olumlu sonuçlara ulaşılmasını sağlayabileceği düşünülmektedir.

\section{Kaynaklar}

Alvarez, R., Terrados, N., Ortolano, R., Iglesias-Cubero, G., Reguero, J.R., Batalla, A. ve ark. (2000). Genetic variation in the renin-angiotensin system and athletic performance. Eur J Appl Physiol., 82(1-2), 117-120.

Ahmetov, I.I. ve Fedotovskaya, O.N. (2015). Current Progress in Sports Genomics. Adv Clin Chem., 70, 247-314.

Ahmetov, I.I. ve Rogozkin, V.A. (2009). Genes, athlete status and training -- An overview. Med Sport Sci., 54, 43-71.

Ash, G.I., Scott, R.A., Deason, M., Dawson, T.A., Wolde, B., Bekele, Z. ve ark. (2011). No association between ACE gene variation and endurance athlete status in Ethiopians. Med Sci Sports Exerc., 43(4), 590-597.

Bayraktar, B. ve Kurtoğlu, M. (2009). Sporda performans, etkili faktörler, değerlendirilmesi ve artırılması. Klinik Gelişim, 22(1), 16-24.

Bray, M.S., Hagberg, J.M., Perusse, L., Rankinen, T., Roth, S.M., Wolfarth, B. ve ark. (2009). The human gene map for performance and health-related fitness phenotypes: the 2006-2007 update. Med Sci Sports Exerc., 41, 35-73.

Brewster, U.C. ve Perazella, M.A. (2004). The renin-angiotensin-aldosterone system and the kidney: Effects on kidney disease. Am J Med., 116, 263-72.

Cieszczyk, P., Krupecki, K., Maciejewska, A., Sawczuk, M. (2009). The angiotensin converting enzyme gene I/D polymorphism in polish rowers. Int J Sports Med., 30, 624-627.

Collins, M., Xenophontos, S.L., Cariolou, M.A., Mokone, G.G., Hudson, D.E., Anastasiades, L. ve ark. (2004). The ACE gene and endurance performance during the South African Ironman Triathlons. Med Sci Sports Exerc., 36, 13141320.

Costa, A.M., Silva, A.J., Garrido, N., Louro, H., Marinho, D.A., Cardoso Marques, M. ve ark. (2009). Angiotensin-converting enzyme genotype affects skeletal muscle strength in elite athletes. J Sports Sci Med., 8, 410-418. 
Costa, A.M., Silva, A.J., Garrido, N.D., Louro, H., de Oliveira, R.J., Breitenfeld, L. (2009). Association between ACE D allele and elite short distance swimming. Eur J Appl Physiol., 106, 785-790.

De Moor, M.H., Spector, T.D., Cherkas, L.F., Falchi, M., Hottenga, J.J., Boomsma, D.I. ve ark. (2007). Genome wide linkage scan for athlete status in 700 British female DZ twin pairs. Twin Res Hum Genet.,10(6), 812-820.

Drozdovska, S.B., Dosenko, V.E., Ahmetov, I.I., Ilyin, V.N. (2013). The association of gene polymorphisms with athlete status in Ukrainians. Biol Sport., 30(3), 163167.

Durmic, T.S., Zdravkovic, M.D., Djelic, M.N., Gavrilovic, T.D., Djordjevic Saranovic, S.A. Plavsic, J.N. ve ark. (2017). Polymorphisms in ACE and ACTN3 genes and blood pressure response to acute exercise in elite male athletes from Serbia. Tohoku J Exp Med., 243(4), 311-320.

Eider, J., Cieszczyk, P., Ficek, K., Leonska-Duniec, A., Sawczuk, M, MaciejewskaKarlowska, A. ve ark. (2013). The association between D allele of the ACE gene and power performance in Polish elite athletes. Association entre l'allèle $D$ du gène $A C E$ et les performances en force chezdes sportifs polonais de haut niveau. Science \& Sports, 28, 325-330.

Folland, J., Leach, B., Little, T., Hawker, K., Myerson, S., Montgomery, H. ve ark. (2000). Angiotensin-converting enzyme genotype affects the response of human skeletal muscle to functional overload. Exp Physiol., 85, 575-579.

Gayagay, G., Yu, B., Hambly, B., Boston, T., Hahn, A., Celermajer, D.S. ve ark. (1998). Elite endurance athletes and the ACE I allele: the role of genes in athletic performance. Hum Genet., 103(1), 48-50.

Gunel, T., Gumusoglu, E., Hosseini, M.K., Yilmazyildirim, E., Dolekcap, I., Aydınlı, K. (2014). Effect of angiotensin I-converting enzyme and $\alpha$-actinin-3 gene polymorphisms on sport performance Mol Med Rep., 9, 1422-1426.

Günay, M., Ülküer, Kurtuluş M., Çelenk, Ç., Bezci, Ş., Gökdemir, K., Gevat, C., Kesici, T. (2010). Angiotensin-converting enzyme polymorphism in elite taekwondo athletes of Turkish and Azerbaijan taekwondo teams. Ovidius University Annals. Series Physical Education and Sport / Science, Movement and Health, 10(2), 165-168.

Jones, A., Montgomery, H.E., Woods, D.R. (2002). Human performance: A role for the ACE genotype? Exerc Sport Sci Rev., 30,184-190. 
Kikuchi, N., Min, S.K., Ueda, D., Igawa, S., Nakazato, K. (2012). Higher frequency of the ACTN3 R allele + ACE DD genotype in Japanese elite wrestlers. J Strength Cond Res., 26(12), 3275-3280.

Kim, C.H., Cho, J.Y., Jeon, J.Y., Koh, Y.G., Kim, Y.M., Kim, H.J. ve ark. (2010). ACE DD genotype is unfavorable to Korean short-term muscle power athletes. Int J Sports Med., 31(1), 65-71.

Lindpaintner, K., Pfeffer, M.A., Kreutz, R., Stampfer, M.J., Grodstein, F., LaMotte, F. ve ark. (1995). A prospective evaluation of an angiotensin-converting-enzyme gene polymorphism and the risk of ischemic heart disease. N Engl J Med., 332, 706-711.

Lucia, A., Gomez-Gallego, F., Chicharro, J., Hoyos, J., Celaya, K., Cordova, A. (2005). Is there no association between ACE and CKMM polymorphisms and cycling performance status during 3-weeks races? Int J Sports Med., 26(6), 442-447.

Ma, F., Yang, Y., Li, X., Zhou, F., Gao, C., Li, M. ve ark. (2013). The association of sport performance with ACE and ACTN3 genetic polymorphisms: a systematic review and meta-analysis. PLoS One, 8, e54685.

Macarthur, D.G. ve North, K.N. (2005). Genes and human elite athletic performance. Hum Genet., 116, 331-339.

Mattei, M.G., Hubert, C., Alhenc-Gelas, F., Roeckel, N., Corvol, P., Soubrier F. (1989). Angiotensin I converting enzyme gene is on chromosome 17. Cytogenet Cell Genet., 51, 1041-1045.

Min, S.K., Takahashi, K., Ishigami, H., Hiranuma, K., Mizuno, M., Ishii, T., ve ark. (2009). Is there a gender difference between ACE gene and race distance? Appl Physiol Nutr Metab., 34(5), 926-932.

Montgomery, H.E., Marshall, R., Hemingway, H., Myerson, S., Clarkson, P., Dollery, C., ve ark. (1998). Human gene for physical performance. Nature, 393(6682), 221-222.

Moran, C.N., Vassilopoulos, C., Tsiokanos, A., Jamurtas, A.Z., Bailey, M.E., Montgomery, H.E. ve ark. (2006). The associations of ACE polymorphisms with physical, physiological and skill parameters in adolescents. Eur J Hum Genet., 14, 332-339. 
Murphey, L.J., Gainer, J.V., Vaughan, D.E., Brown, N.J. (2000). Angiotensinconverting enzyme insertion/deletion polymorphism modulates the human in vivo metabolism of bradykinin. Circulation, 102, 829-632.

Myerson, S., Hemingway, H., Budget, R., Martin, J., Humphries, S., Montgomery, H. (1999). Human angiotensin I-converting enzyme gene and endurance performance. J Appl Physiol., 87(4), 1313-1316.

Nagashima, J., Musha, H., Takada, H., Awaya, T., Oba, H., Mori, N. ve ark. (2000). Influence of angiotensin-converting enzyme gene polymorphism on development of athlete's heart. Clin Cardiol., 23, 621-624.

Nazarov, I.B., Woods, D.R., Montgomery, H.E., Shneider, O.V., Kazakov, V.I., Tomilin, N.V. ve ark. (2001). The angiotensin converting enzyme I/D polymorphism in Russian athletes. Eur J Hum Genet., 9, 797-801.

Oh, S.D. (2007). The distribution of I/D polymorphism in the ACE gene amongKorean male elite athletes. J Sports Med Phys Fitness., 47(2), 250-254.

Oktem, F., Sirin, A., Bilge, I., Emre, S., Ağaçhan, B., Ispir, T. (2004). ACE I/D gene polymorphism in primary FSGS and steroid-sensitive nephrotic syndrome. Pediatr Nephrol., 19, 384-389.

Orysiak, J., Zmijewski, P., Klusiewicz, A., Kaliszewski, P., Malczewska-Lenczowska, J., Gajewski, J. ve ark. (2013). The association between ace gene variation and aerobic capacity in winter endurance disciplines. Biol Sport., 30(4), 249-253.

Ostrander, E.A., Huson, H.J. ve Ostrander, G.K. (2009). Genetics of athletic performance. Annu Rev Genomics Hum Genet., 10, 407-429.

Papadimitriou, I.D., Papadopoulos, C., Kouvatsi, A., Triantaphyllidis, C. (2009). The ACE I/D polymorphism in elite Greek track and field athletes. J Sports Med Phys Fit., 49, 459-463.

Phillips, P.C. (2008). Epistasis--the essential role of gene interactions in the structure and evolution of genetic systems. Nat Rev Genet., 9(11), 855-67.

Puthucheary, Z., Skipworth, J.R., Rawal, J., Loosemore, M., Van Someren, K., Montgomery, H.E. (2011). The ACE gene and human performance: 12 years on. Sports Med., 41(6), 433-448.

Rankinen, T., Wolfarth, B., Simoneau, J.A., Maier-Lenz, D., Rauramaa, R., Rivera M.A. ve ark., (2000). No association between the angiotensin-converting enzyme ID polymorphism and elite endurance athlete status. J Appl Physiol., 88(5), 1571-1575. 
Rigat, B., Hubert, C., Alhenc-Gelas, F., Cambien, F., Corvol, P., Soubrier, F. (1990). An insertion/deletion polymorphism in the angiotensin I-converting enzyme gene accounting for half the variance of serum enzyme levels. J Ciln Invest., 86(4), 1343-1346.

Rigat, B., Hubert, C., Corvol, P., Soubrier, F. (1992). PCR Detection of the Insertion/Deletion of the Human Angiotensin Converting Enzyme Gene (DCP 1) (Dipeptidyl Carboxypeptidase 1). Nucleic Acids Res., 20(6), 1433.

Sambrook, J., Fritsch, E.F., Maniatis, T. (1989). Molecular Cloning. Cold Spring Harbor, Cold Spring Harbor, NY, USA.

Scanavini, D., Bernardi, F., Castoldi, E., Conconi, F., Mazzoni, G. (2002). Increased frequency of the homozygous II ACE genotype in Italian Olympic endurance athletes. Eur J Hum Genet., 10(10), 576-577.

Scott, R.A., Irving, R., Irwin, L., Morrison, E., Charlton, V., Austin, K. ve ark. (2010). ACTN3 and ACE genotypes in elite Jamaican and US sprinters. Med Sci Sports Exerc., 42, 107-112.

Scott, R.A., Moran, C., Wilson, R.H., Onywera, V., Boit, M.K., Goodwin, W.H. ve ark. (2005). No association between Angiotensin Converting Enzyme (ACE) gene variation and endurance athlete status in Kenyans. Comp Biochem Physiol Part A: Mol Integr Physiol., 141(2), 169-175.

Sercan, C., Eken, B.F., Erel, Ş., Ülgüt, D., Kapıcı, S., Ulucan, K. (2016). Spor genetiği ve ACE gen ilişkisi. İnönü Üniversitesi, Beden Eğitimi ve Spor Bilimleri Dergisi, 3(2), 26-34.

Shahmoradi, S., Ahmadalipour, A., Salehi, M. (2014). Evaluation of ACE gene I/Dpolymorphism in Iranian elite athletes. Adv Biomed Res., 3, 207.

Sonna, L.A., Sharp M.A., Knapik, J.J., Cullivan, M., Angel, K.C., Patton, J.F. ve ark. (2001). Angiotensin-converting enzyme genotype and physical performance during US Army basic training. J Appl Physiol., 91(3), 1355-1363.

Spriet, L.L. (2018). Nutritional and Environmental Influences on Athlete Health and Performance. Sports Med., 48(Suppl 1),1-2.

Süel, E. ve Pehlivan, A. (2015). Angiotensin dönüştürücü (converting) enzim (ACE) gen polimorfizminin elit basketbolcu ve voleybolcularda karşılaştırılması. Uluslararası Spor, Egzersiz ve Antrenman Bilimi Dergisi, 1(1), 40-50. 
Taylor, R.R., Mamotte, C.D.S., Fallon, K., van Bockxmeer, F.M. (1999). Elite athletes and the gene for angiotensin-converting enzyme. J Appl Physiol., 87(3), 10351037.

Thomis, M.A., Huygens, W., Heuninckx, S., Chagnon, M., Maes, H.H., Claessens, A.L. ve ark. (2004). Exploration of myostatin polymorphisms and the angiotensin-converting enzyme insertion/deletion genotype in responses of human muscle to strength training. Eur J Appl Physiol., 92(3), 267-274.

Tsianos, G., Sanders, J., Dhamrait, S., Humphries, S., Grant, S., Montgomery, H. (2004). The ACE gene insertion/deletion polymorphism and elite endurance swimming. Eur J Appl Physiol., 92, 360-362.

Turgut, G., Turgut, S., Genc, O., Atalay, A., Atalay E.O. (2004). The angiotensin converting enzyme I/D polymorphism in Turkish athletes and sedentary controls. Acta Medica (Hradec Kralove), 47(2), 133-136.

Williams, A.G., Rayson, M.P., Jubb, M., World, M., Woods, D.R., Hayward M. ve ark. (2000). Physiology: The ACE gene and muscle performance. Nature, 403(6770), 614.

Woods, D., Hickman, M., Jamshidi, Y., Brull, D., Vassiliou, V., Jones, A. ve ark. (2001). Elite swimmers and the D allele of the ACE I/D polymorphism. Hum Genet., 108, 230-232.

Woods, D.R., World, M., Rayson, M.P., Williams, A.G., Jubb, M., Jamshidi, Y. ve ark. (2002). Endurance enhancement related to the human angiotensin I-converting enzyme I-D polymorphism is not due to differences in the cardiorespiratory response to training. Eur J Appl Physiol., 86(3), 240-244.

Zhang, B., Tanaka, H., Shono, N., Miura, S., Kiyonaga, A., Shindo, M. ve ark. (2003). The I allele of the angiotensin-converting enzyme gene is associated with an increased percentage of slow-twitch type I fibers in human skeletal muscle. Clin Genet., 63(2), 139-144. 